Article

\title{
Capacity of Pseudomonas Strains to Degrade Hydrocarbons, Produce Auxins and Maintain Plant Growth under Normal Conditions and in the Presence of Petroleum Contaminants
}

\author{
Margarita Bakaeva, Elena Kuzina, Lidiya Vysotskaya, Guzel Kudoyarova *, Tat'yana Arkhipova, \\ Gulnaz Rafikova, Sergey Chetverikov, Tat'yana Korshunova, Dar'ya Chetverikova \\ and Oleg Loginov \\ Ufa Institute of Biology, Ufa Federal Research Centre, Russian Academy of Sciences, Ufa 450054, Russia; \\ margo22@yandex.ru (M.B.); misshalen@mail.ru (E.K.); vysotskaya@anrb.ru (L.V.); tnarkhipova@mail.ru (T.A.); \\ rgf07@mail.ru (G.R.); che-kov@mail.ru (S.C.); lab.biotech@yandex.ru (T.K.); belka-strelka8031@yandex.ru (D.C.); \\ biolab316@yandex.ru (O.L.) \\ * Correspondence: guzel@anrb.ru; Tel.: +7-919-142-7994
}

Received: 4 February 2020; Accepted: 18 March 2020; Published: 19 March 2020

\begin{abstract}
The phytoremediation of soil contaminated with petroleum oil products relies on co-operation between plants and rhizosphere bacteria, including the plant growth-promoting effect of the bacteria. We studied the capacity of strains of Pseudomonas, selected as oil degraders, to produce plant hormones and promote plant growth. Strains with intermediate auxin production were the most effective in stimulating the seedling growth of seven plant species under normal conditions. Bacterial seed treatment resulted in about a 1.6-fold increase in the weight of barley seedlings, with the increment being much lower in other plant species. The strains P. plecoglossicida 2.4-D and P. hunanensis IB C7, characterized by highly efficient oil degradation (about 70\%) and stable intermediate in vitro auxin production in the presence of oil, were selected for further study with barley. These strains increased the seed germination percentage approximately two-fold under $5 \%$ oil concentration in the soil, while a positive effect on further seedling growth was significant when the oil concentration was raised to $8 \%$. This resulted in a 1.3-1.7-fold increase in the seedling mass after 7 days of growth, depending on the bacterial strain. Thus, strains of oil-degrading bacteria selected for their intermediate and stable production of auxin were found to be effective ameliorators of plant growth inhibition resulting from petroleum stress.
\end{abstract}

Keywords: auxin; petroleum pollution; phytoremediation; plant growth promoting bacteria

\section{Introduction}

Oil-producing and oil-refining industries result in the global contamination of the environment with hydrocarbons, which are toxic for plants, animals and humans [1-3]. Consequently, the goal of the development and application of effective approaches for the remediation of land contaminated with oil is of considerable current interest. Sowing wild and cultivate species on soils contaminated with oil is frequently used as a means of remediation [4-6]. The resulting plant population prevents soil erosion and helps to detoxify hydrocarbons and support higher numbers of hydrocarbon-oxidizing microorganisms. This effect has been ascribed to root exudates providing a substrate for bacterial growth [7-10]. The development of root systems also increases soil porosity, thereby elevating the mass transfer of respiratory substrates and electron acceptors [11]. Plants are tolerant of numerous environmental contaminants and are often used within phytoremediation strategies, but their biomass 
accumulation (and thereby the rate of contaminant removal) may be limited in the presence of high contamination [12]. Adding plant growth-promoting bacteria (PGPB) to soil can increase the accumulation of plant biomass in the presence of petroleum pollutants $[13,14]$ and also increase plant tolerance to other stresses [15] such as drought [16,17], a deficiency of mineral nutrients [18], and presence of pesticides [19]. Thus, combining the capacity of petroleum destruction and the promotion of plant growth in the same bacterial culture is a promising approach to phytoremediation.

Some reports suggest that certain plant hormones can ameliorate the negative effects of oil pollution on plants. Han et al. [20] showed that the plant hormone brassinolide could promote the photosynthesis of Robinia pseudoacacia seedlings in petroleum-stress conditions, thereby counteracting its adverse effects. Microorganisms can directly influence plant growth by synthesizing growth-stimulating hormones [21-23]. Nevertheless, only a small number of publications have addressed the synthesis of hormones by plant growth promoting rhizobacteria (PGPR) under conditions of oil pollution and their phytoremedial effect on plants. For example, a model system consisting of bacteria (Sinorhizobium meliloti) capable of associative nitrogen fixation, hydrocarbon oxidation, and the production of auxins in combination with a grass (Sorghum bicolor) has been successfully used for the remediation of soils contaminated with polycyclic aromatic hydrocarbons [24]. Testing free living bacteria of Pseudomonas as hormone producers and plant growth promoters under conditions of contamination with petroleum is of no less interest than the study of associative bacteria, since the capacity for the active decomposition of hydrocarbons and resistance to adverse environmental conditions have been detected in many representatives of this genus [25-27].

The goal of the present work was to study the ability of strains of Pseudomonas bacteria known to be effective in breaking-down oil hydrocarbons to synthesize auxins and to follow their effects on the growth of plants in normal conditions and under petroleum stress. We have chosen the following plant species which have been reported to be relatively resistant to petroleum pollutants to study the effects of seed inoculation on germination and seedling growth under normal conditions and in the presence of oil or individual hydrocarbons: oats (Avena sativa L. [4]), barley (Hordeum vulgare L. [28]), Sudan grass (Sorghum $\times$ drummondii [29]), pea (Pisum sativum L. [30]), smooth brome (Bromus inermis Leyss [31]), meadow fescue (Festuca pratensis Huds. [32]), and clover (Trifolium pratense L. [33]).

\section{Results and Discussion}

\subsection{Properties of Microorganisms}

Six strains belonging to different species of Pseudomonas were selected from a collection at the Ufa Institute of Biology, Ufa Federal Research Centre, Russian Academy of Sciences (UIB UFRC RAS) as being capable of oxidizing oil products and accumulating indole-3-acetic acid (IAA) in culture media. Their characteristics are presented in Tables 1 and 2. A description of the Pseudomonas turukhanskensis IB 1.1 strain was reported by Korshunova et al. [25], while the P. plecoglossicida 2.4-D strain was described in the article by Chetverikov et al. [34].

Table 1. Species affiliation and origin of bacterial strains used in the experiments.

\begin{tabular}{cccc}
\hline $\begin{array}{c}\text { Strain Number in the } \\
\text { Collection of UIB UFRC RAS }\end{array}$ & Species/Strain & $\begin{array}{c}\text { 16S rRNA Nucleotide } \\
\text { Sequence Similarity, \% }\end{array}$ & Strain Origin \\
\hline IB K2 & $\begin{array}{c}\text { Pseudomonas } \\
\text { extremaustralis 14-3 }\end{array}$ & 99.93 & $\begin{array}{c}\text { Soil contaminated with oil } \\
\text { (Republic of Bashkortostan, } \\
\text { Russia) }\end{array}$ \\
IB C7 (B-3229D) & $\begin{array}{c}\text { P. hunanensis LV } \\
\text { P. nitroreducens } \\
\text { DSM 14399 }\end{array}$ & 99.56 & $\begin{array}{c}\text { Steppe soil (Sol-Iletsky District, } \\
\text { Orenburg region, Russia) } \\
\text { Soil from the site of oil spill } \\
\text { (Khanty-Mansi Autonomous } \\
\text { Area, Russia) }\end{array}$ \\
IB ND 1.1 & 99.90 & $\begin{array}{c}\text { Bilge water from a transport } \\
\text { vessel (port of Novorossiysk, } \\
\text { Russia) }\end{array}$ \\
\hline KCTC 32246 & 99.06 & \\
\hline
\end{tabular}


Table 2. Degradation of oil and oil products by strains of Pseudomonas after 3 days of cultivation on Raymond media containing $2 \mathrm{~g} \mathrm{~L}^{-1}$ of hydrocarbon substrate.

\begin{tabular}{|c|c|c|c|c|c|}
\hline \multirow{2}{*}{ Strains } & \multicolumn{5}{|c|}{ Extent of Degradation of Hydrocarbon Substrate, \% } \\
\hline & Oil & Diesel Fuel & $\begin{array}{l}\text { Marine Fuel } \\
\text { Oil }\end{array}$ & $\begin{array}{c}\text { Lubricating } \\
\text { Oil }\end{array}$ & Heavy Fuel Oil \\
\hline $\begin{array}{l}\text { Pseudomonas } \\
\text { extremaustralis } \\
\text { IB K2 }\end{array}$ & $51.3 \pm 0.7^{\mathrm{a}}$ & $65.5 \pm 3.4^{\mathrm{a}}$ & $47.6 \pm 1.3^{\mathrm{a}}$ & $17.1 \pm 0.3^{c}$ & $22.2 \pm 0.3^{d}$ \\
\hline $\begin{array}{l}\text { P. hunanensis } \\
\text { IB C7 }\end{array}$ & $73.0 \pm 1.6^{b}$ & $87.9 \pm 2.2^{c}$ & $59.0 \pm 1.2^{c}$ & $34.7 \pm 0.4^{\mathrm{d}}$ & $24.8 \pm 0.2^{\mathrm{e}}$ \\
\hline $\begin{array}{l}\text { P. nitroreducens } \\
\text { IB ND } 1.1\end{array}$ & $83.3 \pm 1.6^{c}$ & $90.2 \pm 1.8^{c}$ & $45.5 \pm 0.9^{a}$ & $12.0 \pm 0.3^{\mathrm{a}}$ & $15.2 \pm 0.4^{b}$ \\
\hline $\begin{array}{l}\text { P. plecoglossicida } \\
\text { 2.4-D }\end{array}$ & $69.0 \pm 1.5^{b}$ & $80.5 \pm 2.0^{b}$ & $\mathrm{Nm}$ & $\mathrm{Nm}$ & $19.7 \pm 0.3^{c}$ \\
\hline $\begin{array}{l}\text { P. sihuiensis } \\
\text { IB P1 }\end{array}$ & $54.0 \pm 1.9^{a}$ & $60.7 \pm 3.2^{\mathrm{a}}$ & $47.9 \pm 1.1^{\mathrm{a}}$ & $13.0 \pm 0.2^{b}$ & $13.8 \pm 0.4^{\mathrm{a}}$ \\
\hline $\begin{array}{c}\text { P. turukhanskensis } \\
\text { IB } 1.1\end{array}$ & $84.5 \pm 2.1^{c}$ & $89.0 \pm 3.0^{c}$ & $51.6 \pm 1.1^{b}$ & $18.0 \pm 0.5^{c}$ & $20.5 \pm 0.5^{c}$ \\
\hline
\end{tabular}

$\mathrm{Nm}-$ not measured. Mean values $\pm \mathrm{SE}$ are presented $(n=10)$. In each column, significantly different means are marked with different letters ( $p \leq 0.05, t$-test).

The presence of petroleum hydrocarbons in the soil is known to make mineral nutrients less accessible for plants [35]. Hydrocarbon-oxidizing bacteria also have an increased need for sources of nitrogen and phosphorus, since they are almost absent from oil products. Therefore, the ability of bacteria to fix atmospheric nitrogen and transfer phosphorus salts into a soluble form could have a positive effect on the phytomelioration of contaminated soils. Among the studied strains, those of P. hunanensis IB C7, P. nitroreducens IB ND 1.1, and P. turukhanskensis IB 1.1 are nitrogen-fixers (diazotrophy) and were found capable of mobilizing water-insoluble phosphates (Figure 1). Nitrogenase activity was significantly higher than in the control (about 14, 13 and $18 \mathrm{mmol}$ of $\mathrm{C}_{2} \mathrm{H}_{4} \mathrm{~h}^{-1} \mathrm{ml}^{-1}$, respectively, with this level being considered rather low). Around the colonies of the P. turukhanskensis IB 1.1 strain, phosphates were dissolved on Pikovskaya medium in a zone with a radius of $12 \mathrm{~mm}$; for P. hunanensis IB C7 strain, the radius was $4 \mathrm{~mm}$; and for P. nitroreducens IB ND, the radius was 1.1-3 $\mathrm{mm}$. In the remaining studied strains, phosphate dissolution was not visually detected, and the values of nitrogenase activity did not differ significantly from the control sample. 


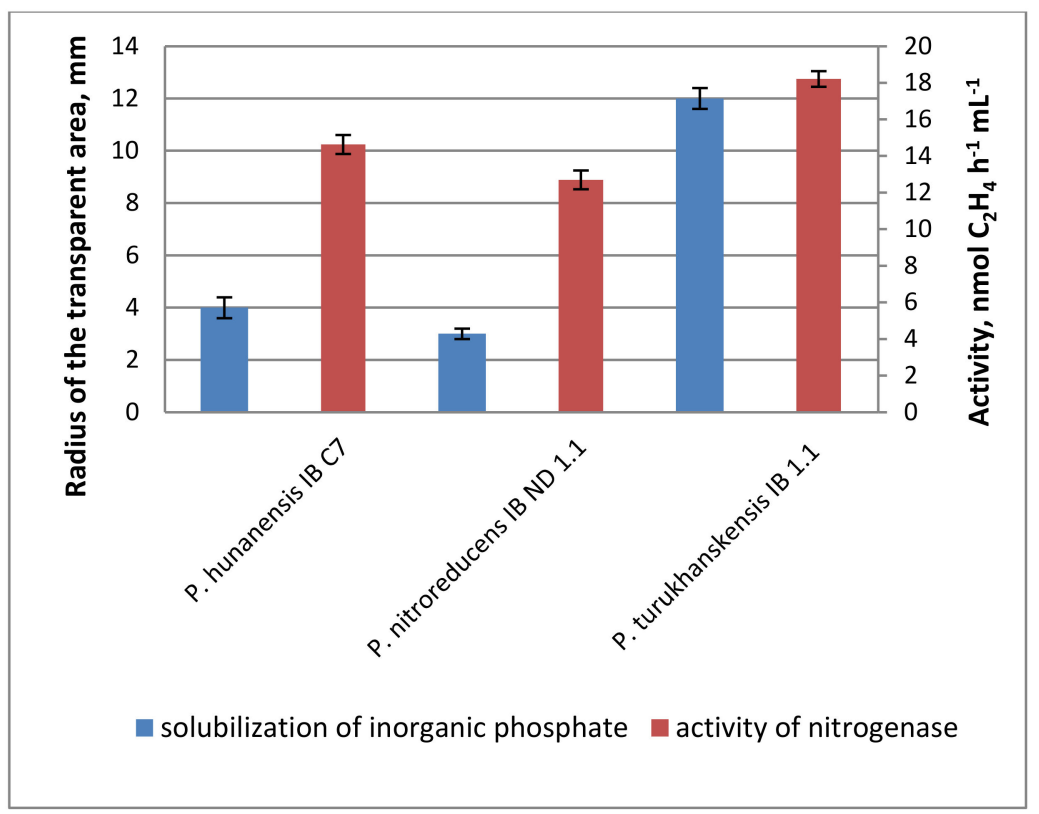

Figure 1. Solubilization of inorganic phosphate and activity of nitrogenase in liquid bacterial cultures of strains P. hunanensis IB C7, P. nitroreducens IB ND 1.1, and P. turukhanskensis IB 1.1. Mean values \pm SE are presented ( $n=10$ plates for phosphate solubilization, $n=$ four flasks investigating the activity of nitrogenase).

To clarify the phylogenetic position of the selected strains and their relationship with each other and with other species of Pseudomonas, a phylogenetic tree was constructed based on the nucleotide sequence of the $16 \mathrm{~S}$ rRNA gene (Figure 2). The dendrogram shows that the strains belong to different clusters.

Table 2 shows that the strains of Pseudomonas we selected could breakdown crude oil, diesel fuel, marine fuel oil, lubricating oil and heavy fuel oil. P. plecoglossicida 2.4-D, P. hunanensis IB C7, P. nitroreducens IB ND 1.1 and P. turukhanskensis IB 1.1 actively destroyed both crude oil and its products, while $P$. extremaustralis IB K2 and P. sihuiensis IB P1 were less active, although $P$. extremaustralis IB K2 was almost as active as P. hunanensis IB C7 in metabolizing heavy fuel oil.

The concentration of the auxin indolyl-3-acetic acid (IAA) in the nutrient medium reached a maximum when cultures were transferred to the stationary phase of growth [18]. At this stage, Pseudomonas spp. significantly differed from each other in their ability to accumulate IAA in liquid culture (Table 3). On this basis, the strains could be divided into groups with high (P. turukhanskensis IB 1.1), intermediate (P. plecoglossicida 2.4-D, P. hunanensis IB C7, P. nitroreducens IB ND 1.1, P. sihuiensis IB P1) or low IAA production (P. extremaustralis IB K2). Cytokinins and abscisic acid were present in much lower concentrations than IAA in the culture media of $0.4-2.8 \mathrm{ng} \mathrm{mL}^{-1}$ and $0.4-1.2 \mathrm{ng}$ $\mathrm{mL}^{-1}$, respectively.

Auxin concentration depended on the presence of oil hydrocarbons in the culture media and varied from about $300 \mathrm{ng} \mathrm{L}^{-1}$ to more than $11000 \mathrm{ng} \mathrm{mL}^{-1}$, when the bacteria grew on contaminant-free medium. Crude oil decreased these values to between $120 \mathrm{ng} \mathrm{mL}^{-1}$ and $6048 \mathrm{ng} \mathrm{mL}^{-1}$, while the range in hexadecane was $84 \mathrm{ng} \mathrm{mL}^{-1}$ to $7301 \mathrm{ng} \mathrm{mL}^{-1}$ and the range in toluene was $83 \mathrm{ng} \mathrm{mL}^{-1}$ to $140 \mathrm{ng}$ $\mathrm{mL}^{-1}$ (Table 3). Thus, the presence of crude oil and its refined products in the culture media decreased the accumulation of IAA. This was probably a result of the inhibition of bacterial growth by these substances (see Table 4). Among the studied strains, P. hunanensis IB C7 was particularly noteworthy, since no significant decrease was found in IAA accumulation in the presence of oil or hexadecane. Toluene had a strong toxic effect on all the cultures, inhibiting both their reproduction (Table 4) and the synthesis of IAA (Table 3). 


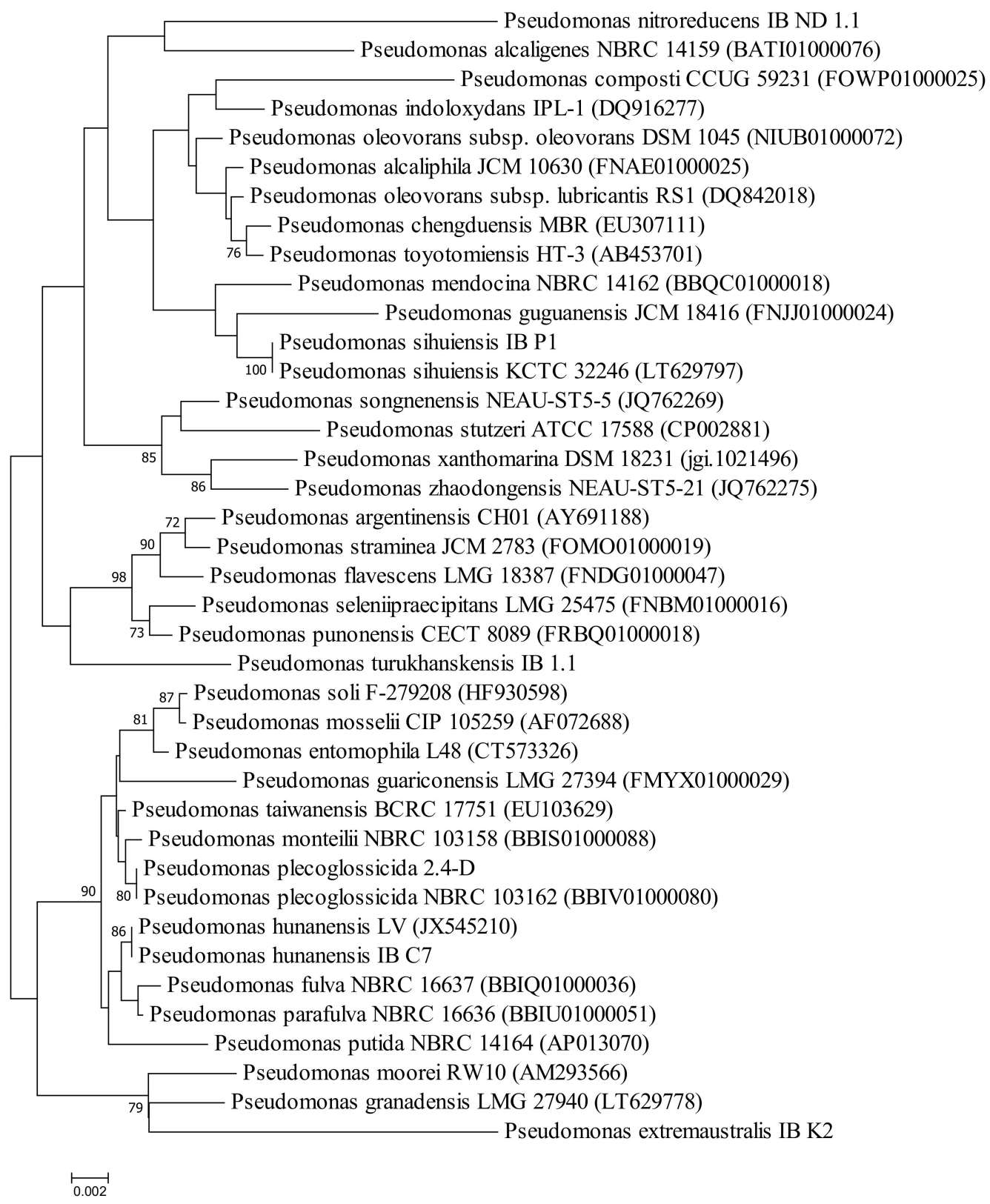

Figure 2. Neighbor-joining phylogenetic tree based on 16S rRNA gene sequences of the selected hydrocarbon-degrading bacteria and closely related species of the genus Pseudomonas. Bootstrap values (expressed as percentages of 1000 replications) are shown at the branching points. Bar-two nucleotide substitutions per $100 \mathrm{nt}$.

Table 3. Auxin production (ng mL $\mathrm{mL}^{-1}$ ) by bacterial strains cultivated on King B medium with different additives: oil, hexadecane and toluene $\left(2 \mathrm{~g} \mathrm{~L}^{-1}\right)$.

\begin{tabular}{ccccc}
\hline Strains & Without Additives & Oil & Hexadecane & Toluene \\
\hline Pseudomonas extremaustralis IB K2 & $318 \pm 37^{\mathrm{c}}$ & $120 \pm 13^{\mathrm{ab}}$ & $84 \pm 3^{\mathrm{a}}$ & $140 \pm 21^{\mathrm{ab}}$ \\
P. hunanensis IB C7 & $661 \pm 88^{\mathrm{d}}$ & $702 \pm 25^{\mathrm{d}}$ & $654 \pm 25^{\mathrm{d}}$ & $80 \pm 5^{\mathrm{a}}$ \\
P. nitroreducens IB ND 1.1 & $1413 \pm 64^{\mathrm{e}}$ & $289 \pm 40^{\mathrm{c}}$ & $692 \pm 94^{\mathrm{d}}$ & $102 \pm 10^{\mathrm{a}}$ \\
P. plecoglossicida 2.4-D & $1205 \pm 72^{\mathrm{e}}$ & $588 \pm 32^{\mathrm{d}}$ & $518 \pm 21^{\mathrm{d}}$ & $89 \pm 4^{\mathrm{a}}$ \\
P. sihuiensis IB P1 & $1324 \pm 38^{\mathrm{e}}$ & $189 \pm 36^{\mathrm{bc}}$ & $698 \pm 7^{\mathrm{d}}$ & $83 \pm 4^{\mathrm{a}}$ \\
P. turukhanskensis IB 1.1 & $11261 \pm 897^{\mathrm{g}}$ & $6048 \pm 809^{\mathrm{f}}$ & $7301 \pm 406^{\mathrm{f}}$ & $154 \pm 12^{\mathrm{b}}$ \\
\hline
\end{tabular}

Mean values \pm SD are presented $(n=12)$. Significantly different means are marked with different letters $(p \leq 0.05$, $t$-test). 
Table 4. The effect of oil, hexadecane and toluene $\left(2 \mathrm{~g} \mathrm{~L}^{-1}\right)$ on number of colonies forming units (CFU $\mathrm{mL}^{-1}$ ) in culture media during the stationary phase of their growth on the King B medium.

\begin{tabular}{ccccc}
\hline \multirow{2}{*}{ Strains } & \multicolumn{3}{c}{ Additives to the Medium } \\
\cline { 2 - 5 } & $\begin{array}{c}\text { Without } \\
\text { Additives }\end{array}$ & + Oil & + Hexadecane & + Toluene \\
\hline Pseudomonas extremaustralis IB K2 & $(5.1 \pm 0.2) \times 10^{9}$ & $(1.8 \pm 0.1) \times 10^{8}$ & $(2.0 \pm 0.1) \times 10^{8}$ & $(2.0 \pm 0.1) \times 10^{5}$ \\
P. hunanensis IB C7 & $(7.9 \pm 0.2) \times 10^{9}$ & $(8.0 \pm 0.2) \times 10^{8}$ & $(1.0 \pm 0.1) \times 10^{9}$ & $(3.0 \pm 0.1) \times 10^{5}$ \\
P. nitroreducens IB ND 1.1 & $(5.7 \pm 0.3) \times 10^{9}$ & $(2.6 \pm 0.1) \times 10^{8}$ & $(2.3 \pm 0.1) \times 10^{8}$ & $<10^{5}$ \\
P. plecoglossicida 2.4-D & $(5.4 \pm 0.3) \times 10^{9}$ & $(2.0 \pm 0.1) \times 10^{8}$ & $(2.6 \pm 0.1) \times 10^{8}$ & $<10^{5}$ \\
P. sihuiensis IB P1 & $(1.0 \pm 0.1) \times 10^{10}$ & $(9.0 \pm 0.2) \times 10^{7}$ & $(8.0 \pm 0.2) \times 10^{7}$ & $<10^{5}$ \\
P. turukhanskensis IB 1.1 & $(4.0 \pm 0.2) \times 10^{9}$ & $(7.4 \pm 0.2) \times 10^{8}$ & $(3.3 \pm 0.2) \times 10^{8}$ & $<10^{5}$ \\
\hline
\end{tabular}

Mean values \pm SE are presented $(n=12)$.

A weak overall correlation $(r=0.5)$ was found between the decline in IAA accumulation in the culture medium under the influence of oil and the rate of oil destruction by bacteria of individual strains. It is likely that ability of P. hunanensis IB C7 to synthesize IAA in amounts unaffected by oil or hexadecane is not related directly with its oil breakdown activity.

\subsection{Effect of Microorganisms on Plants}

The seven plant species used were selected on the basis of being known as somewhat resistant to oil contamination of soil: oats (Avena sativa L. [4]), barley (Hordeum vulgare L. [28]), Sudan grass (Sorghum $\times$ drummondii [29]), pea (Pisum sativum L. [30]), smooth brome (Bromus inermis Leyss [31]), meadow fescue (Festuca pratensis Huds. [32]), and clover (Trifolium pratense L. [33]). However, it was important to test how their performance was influenced by the selected hydrocarbon-degrading bacteria. Tables 5 and 6 show that the species differed in their growth response to seed inoculation with different bacterial strains. An increase in germination percentage under Petri dish conditions was detected in Avena sativa, Hordeum vulgare, Pisum sativum, Bromus inermis, Trifolium pratense, while germination of Sorghum $\times$ drummondii and Festuca pratensis was not changed significantly by any of the six bacterial strains tested (Table 5). The seedling mass of Trifolium pratense, Hordeum vulgare, Pisum sativum, Avena sativa, Festuca pratensis and Sorghum $\times$ drummondii after 7 days from imbibition was increased by bacterial treatment but had no promoting effect on Bromus inermis (Table 6). Growth promotion was mostly detected when seeds were inoculated with bacterial strains characterized by an intermediate accumulation of auxin in the culture medium. Thus, seed treatment with P. hunanensis IB C7 strain increased germination in three plant species and increased the seedling mass in five out of seven species. Similarly, P. nitroreducens IB ND 1.1 elevated germination in two species and seedling mass in five species while P. plecoglossicida 2.4-D did so in four and two species and P. sihuiensis IB P1 improved germination a subsequent seedling growth in two and three species, respectively. P. extremaustralis IB $\mathrm{K} 2$, characterized by relatively low levels of IAA accumulation in the culture media, did not influence seed germination in any of the species tested and stimulated mass accumulation in only two species, while P. turukhanskensis IB 1.1 (a strain generating extremely high levels of auxin in the culture medium) stimulated germination and mass accumulation less than bacterial strains with intermediate level of auxin accumulation (in two and one plant species, correspondingly (Table 6). 
Table 5. Effect of inoculating seeds with strains of Pseudomonas bacteria on percentage seed germination in Petri dishes after 7 days.

\begin{tabular}{|c|c|c|c|c|c|c|c|}
\hline Plant Species & $\begin{array}{c}\text { Pseudomonas } \\
\text { extremaustralis IB K2 }\end{array}$ & $\begin{array}{l}\text { P. hunanensis IB } \\
\text { C7 }\end{array}$ & $\begin{array}{l}\text { P. nitroreducens } \\
\text { IB ND } 1.1\end{array}$ & $\begin{array}{c}\text { P. plecoglossicida } \\
\text { 2.4-D }\end{array}$ & P. sihuiensis IB P1 & $\begin{array}{l}\text { P. turukhanskensis IB } \\
1.1\end{array}$ & Control \\
\hline Avena sativa & $34.40 \pm 1.33$ & $39.00 \pm 1.15$ & $56.10 \pm 2.14$ & $52.50 \pm 1.82$ & $36.60 \pm 1.50$ & $37.50 \pm 1.26$ & $40.00 \pm 2.05$ \\
\hline Bromus inermis & $57.90 \pm 2.30$ & $73.33 \pm 1.04$ & $66.05 \pm 2.17$ & $69.38 \pm 1.76$ & $56.65 \pm 1.22$ & $59.38 \pm 1.08$ & $59.18 \pm 1.40$ \\
\hline Festuca pratensis & $40.62 \pm 1.85$ & $44.38 \pm 1.35$ & $37.00 \pm 1.28$ & $39.38 \pm 1.15$ & $43.75 \pm 2.18$ & $40.63 \pm 1.43$ & $43.13 \pm 1.07$ \\
\hline Hordeum vulgare & $96.65 \pm 2.5$ & $96.65 \pm 2.42$ & $96.65 \pm 1.98$ & $91.65 \pm 2.13$ & $97.50 \pm 1.63$ & $97.50 \pm 1.54$ & $91.65 \pm 2.00$ \\
\hline Pisum sativum & $95.00 \pm 2.73$ & $96.65 \pm 1.84$ & $90.00 \pm 2.87$ & $98.35 \pm 2.15$ & $98.35 \pm 2.35$ & $95.00 \pm 2.46$ & $91.10 \pm 1.55$ \\
\hline $\begin{array}{l}\text { Sorghum } \times \\
\text { drummondii }\end{array}$ & $80.00 \pm 3.12$ & $83.35 \pm 2.25$ & $88.35 \pm 2.08$ & $82.50 \pm 1.81$ & $78.35 \pm 3.07$ & $83.35 \pm 2.85$ & $83.35 \pm 2.54$ \\
\hline Trifolium pratense & $39.18 \pm 1.50$ & $\mathbf{6 0 . 0 0} \pm 1.49$ & $69.18 \pm 1.88$ & $60.83 \pm 1.43$ & $36.88 \pm 1.40$ & $60.00 \pm 1.80$ & $35.00 \pm 1.39$ \\
\hline
\end{tabular}

Mean values \pm SE are presented ( $n=10$ ). Mean values for treated plants significantly different from the control (untreated plants, $p \leq 0.05, t$-test) are marked with bold letters.

Table 6. Effect of inoculating seeds with strains of Pseudomonas bacteria on the mass of seedlings of plant species grown in Petri dishes in the absence of oil, hexadecane or toluene.

\begin{tabular}{|c|c|c|c|c|c|c|c|}
\hline Plant Species & $\begin{array}{c}\text { Pseudomonas } \\
\text { extremaustralis IB K2 }\end{array}$ & $\begin{array}{c}\text { P. hunanensis IB } \\
\text { C7 }\end{array}$ & $\begin{array}{l}\text { P. nitroreducens } \\
\text { IB ND } 1.1\end{array}$ & $\begin{array}{c}\text { P. plecoglossicida } \\
\text { 2.4-D }\end{array}$ & P. sihuiensis IB P1 & $\begin{array}{l}\text { P. turukhanskensis IB } \\
1.1\end{array}$ & Control \\
\hline Avena sativa & $86.0 \pm 1.2$ & $112.4 \pm 2.3$ & $80.5 \pm 0.9$ & $99.3 \pm 1.6$ & $75.3 \pm 1.1$ & $74.6 \pm 1.8$ & $69.0 \pm 1.5$ \\
\hline Bromus inermis & $21.5 \pm 0.41$ & $20.6 \pm 0.18$ & $17.7 \pm 0.58$ & $20.2 \pm 0.43$ & $17.3 \pm 0.53$ & $23.7 \pm 0.61$ & $19.5 \pm 0.29$ \\
\hline Festuca pratensis & $3.90 \pm 0.18$ & $4.88 \pm 0.07$ & $4.23 \pm 0.09$ & $3.88 \pm 0.24$ & $4.72 \pm 0.08$ & $4.84 \pm 0.09$ & $4.06 \pm 0.10$ \\
\hline Hordeum vulgare & $150 \pm 3$ & $172 \pm 5$ & $160 \pm 3$ & $156 \pm 4$ & $179 \pm 5$ & $179 \pm 5$ & $105 \pm 2$ \\
\hline Pisum sativum & $626 \pm 9$ & $643 \pm 4$ & $702 \pm 10$ & $591 \pm 14$ & $669 \pm 4$ & $602 \pm 5$ & $598 \pm 4$ \\
\hline $\begin{array}{l}\text { Sorghum } \times \\
\text { drummondii }\end{array}$ & $28.0 \pm 0.4$ & $40.2 \pm 0.9$ & $37.7 \pm 0.6$ & $44.1 \pm 0.6$ & $39 \pm 0.7$ & $41.3 \pm 1.0$ & $34 \pm 0.5$ \\
\hline Trifolium pratense & $2.67 \pm 0.27$ & $6.05 \pm 0.25$ & $4.53 \pm 0.23$ & $2.54 \pm 0.04$ & $2.84 \pm 0.14$ & $2.76 \pm 0.17$ & $2.60 \pm 0.25$ \\
\hline
\end{tabular}

Comments: Mean values \pm SE are presented $(n=40)$. Mean values for treated plants significantly different from the control (untreated plants, $p \leq 0.05, t$-test) are marked with bold letters. 
The absence of plant growth promotion by low-auxin bacteria confirms the importance of this hormone for the bacterial effect on plant growth (Spaepen and Vanderleyden [21] and references therein). The lack of a stimulating effect in control conditions by the strain with the highest level of auxin production (P. nitroreducens IB ND 1.1.) is in accordance with the ability of a high concentration of IAA to stimulate ethylene production capable of inhibiting plant growth [36].

For further experiments, we chose P. hunanensis IB C7 and P. plecoglossicida 2.4-D strains characterized by an active capacity for degrading hydrocarbons and for promoting seedling growth (Table 2) and with an intermediate but relatively stable level of IAA production (Table 3). These strains were used to inoculate barley seeds sown in soil. Barley was chosen as it proved to be the most responsive to bacterial treatment in Petri dish experiments in the absence of oil (Tables 5 and 6). The presence of oil-polluted soil was found to decrease germination and the growth of barley seedlings untreated with bacteria (Figure 3). The toxic effects of oil pollutants are known to be most important at the early stages of plant growth [29]; therefore, it was important to check whether bacterial inoculation can also stimulate germination and growth in petroleum-stressed-seedlings.

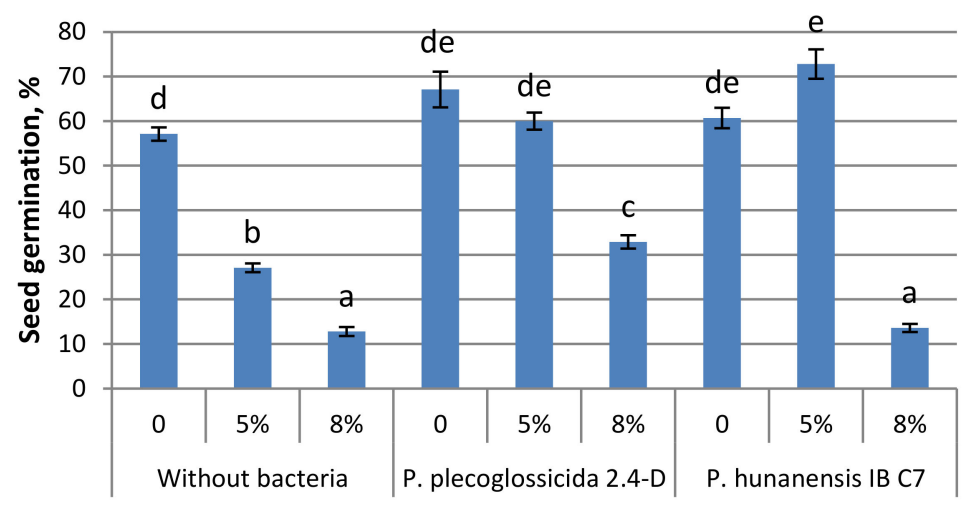

(a)

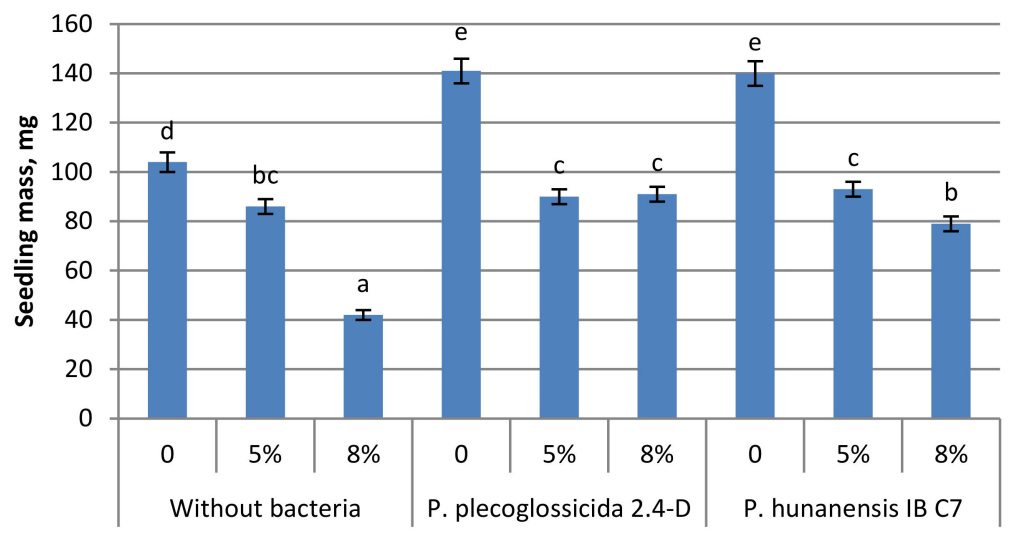

(b)

Figure 3. Cont. 


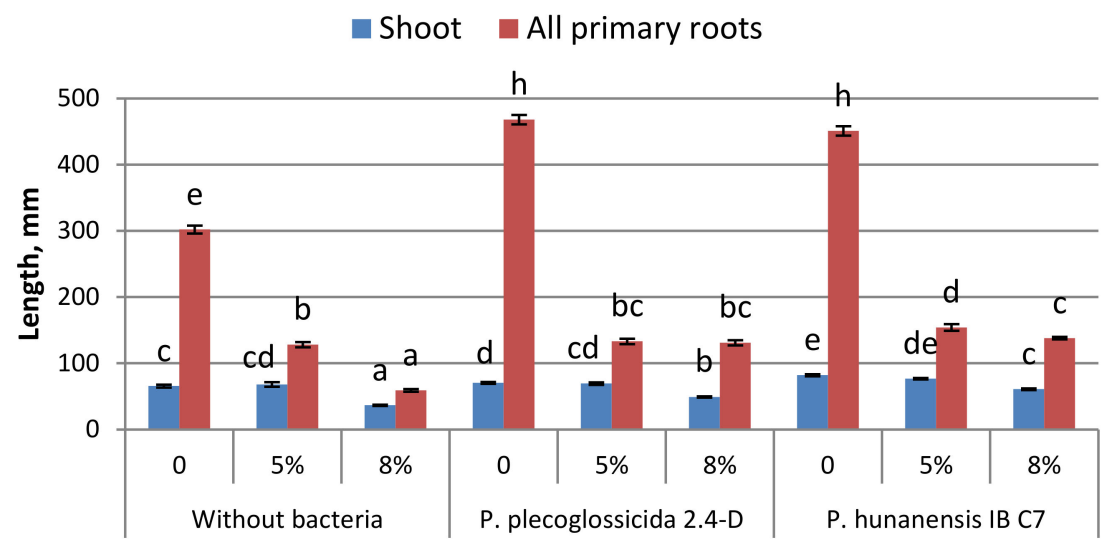

(c)

Figure 3. Effect of oil pollutants (50 and $80 \mathrm{~g} \mathrm{~kg}^{-1}$ soil) and inoculation of seeds with strains of Pseudomonas bacteria on (a) germination, (b) seedling mass and (c) length of barley seedlings grown in soil and measured 7 days after seed soaking. Mean values \pm SE are presented $(n=30)$. Significantly different means of each parameter are marked with different letters $(p \leq 0.05, t$-test).

Inoculation with P. plecoglossicida 2.4-D increased the germination of barley in the absence of oil pollutants and at both 5\% and 8\% oil treatments. Treatment with P. hunanensis IB C7 promoted germination only at the lower oil concentration (5\%) (or without oil pollutant). Thus, the inhibition of germination from oil contamination was diminished by both bacterial strains at $5 \%$ oil contamination but only by P. plecoglossicida 2.4-D at $8 \%$ oil concentration. These findings agree with the Petri dish experiments in Petri dishes, with seedling mass being increased by both bacterial strains in barley grown in containers with soil without oil pollutants. At the lower (5\%) oil concentration in containers of soil, plants treated with the bacterial strains did not significantly differ from the untreated plants in terms of seedling mass and shoot length. At this level of contamination, P. hunanensis IB C7 increased the total length of barley primary roots. The response to higher oil concentration was different. In this case, although soil contamination with oil dramatically decreased plant growth, significant increases in seedling mass or shoot and root length were detected in plants treated with either bacterial strain. Plant growth maintenance under a high level of pollution is likely to result from either the decreased toxicity of pollutants resulting from their active destruction by bacteria or from the direct effect of bacterial hormones.

It is of interest that no nitrogenase or phosphate-mobilizing activity was found in the P. plecoglossicida 2,4-D strain, while the treatment of plants with this strain stimulated their growth against the background of oil pollution. The growth-stimulating activity of these bacteria could perhaps be explained by their ability to synthesize auxins. These results emphasize the importance of the production of hormones by bacteria and their action under stressful conditions. Plants are usually used for the remediation of polluted soil at the late stages of the process, when the concentration of pollutants is already lowered. Table 6 shows that the germination and growth of plants themselves (without bacteria treatment) greatly decreased with an increase in oil concentration. However, seed inoculation with appropriate bacterial strains diminished the extent of growth inhibition caused by increased oil contamination. These results suggest that an inoculation such as this may strengthen the ability of plants to remediate highly contaminated soils.

Thus, strains of bacteria that can more readily metabolize oil or oil-derived products exert a promotive action on germination and mass accumulation by Trifolium pratense, Hordeum vulgare, Pisum sativum, Avena sativa. Such bacterial strains differ from each other in their capacity to accumulate auxins in their culture media, and this capacity decreases in the presence of oil. The stimulating effects of inoculating seeds on plant germination and growth are more clearly pronounced in bacteria with an intermediate and stable level of auxin production. Treating barley seeds with these bacterial strains 
of Pseudomonas in particular was found to increase germination and root growth in soil contaminated with petroleum oil during the first week of germination.

\section{Materials and Methods}

We studied bacterial strains recovered by the authors of the present report from soil and water contaminated with oil and stored in the culture collections of the Ufa Institute of Biology of the Russian Academy of Sciences (UIB, RAS) (Table 1). For the taxonomic affiliation of bacterial strains, 16S rRNA gene nucleotide sequences were determined. Total DNA from bacterial colonies was recovered with the reagent kit «RIBO-sorb» (Amplisens ${ }^{\circledR}$, Central Research Institute of Epidemiology, Moscow, Russian Federation) according to the recommendations of the manufacturer. The amplification of the fragment of the $16 \mathrm{~S}$ rRNA gene was carried out using universal primers: 27F (5'-AGAGTTTGATCTGGCTCAG-3') and 1492R (5'-ACGGTACCTTGTTACGACTT-3') [37]. Sequencing of 16S rRNA was performed using BigDye Terminator Sequencing Kit (Applied Biosystems, Thermo Fisher Scientific Inc., Waltham, MA, USA) with the help of the Genetic Analyzer 3500 xL (Applied Biosystems, Thermo Fisher Scientific Inc., Waltham, MA, USA). To sequester cycle-sequencing reaction components, we used the BigDye ${ }^{\circledR}$ XTerminator ${ }^{\mathrm{TM}}$ Purification Kit (Applied Biosystems, Thermo Fisher Scientific Inc., Waltham, MA, USA). The search for 16S rRNA nucleotide sequences similar to the corresponding sequences of the studied strains was carried out using the GenBank sequence database with the help of the software package BLAST (http://www.ncbi.nlm.nih.gov/blast).

The capacity of bacteria for the oxidation of petroleum hydrocarbons was qualitatively evaluated by measuring their growth on Raymond mineral culture medium $\left(\mathrm{g} \mathrm{L}^{-1}\right)-\mathrm{NH}_{4} \mathrm{NO}_{3}, 2.0 ; \mathrm{MgSO}_{4} \times 7 \mathrm{H}_{2} \mathrm{O}$, $0.2 ; \mathrm{KH}_{2} \mathrm{PO}_{4}, 2.0 ; \mathrm{Na}_{2} \mathrm{HPO}_{4}, 3 ; \mathrm{CaCl}_{2} \times 6 \mathrm{H} 2 \mathrm{O}, 0.01 ; \mathrm{Na}_{2} \mathrm{CO}_{3}, 0.1 ; \mathrm{pH}, 7.0$ [38]—containing $2 \mathrm{~g} \mathrm{~L}^{-1}$ of oil products as the only source of carbon. Quantitative evaluation was carried out by measuring the decline in oil products in Raymond mineral culture medium during the growth of pure bacterial cultures. The following hydrocarbons were used to prepare the culture media: oil (brand Urals), heavy fuel oil, marine fuel oil, diesel fuel, lubricating oil. Concentrations of hydrocarbons in the samples was measured by the Luminescent/Photometric Liquid Analyzer "Fluorat-02" ("Lumex-Marketing", St.-Petersburg, Russia).

To study the capacity of bacteria to produce plant hormones, bacteria were grown on King $\mathrm{B}$ liquid nutrient medium ( $\mathrm{g} \mathrm{L}^{-1}$ )—peptone, 20.0; glycerol, 10.0; $\mathrm{K}_{2} \mathrm{HPO}_{4}, 1.5 ; \mathrm{MgSO}_{4} \times 7 \mathrm{H}_{2}, 1.5$ [39]—to which hydrocarbons were added to yield final concentration of $1 \mathrm{~g} \mathrm{~L}^{-1}$. The transfer of bacterial suspensions of test strains prepared with sterile tap water into the nutrient medium was performed to yield its final titer $(1 \pm 0.5) \times 10^{6} \mathrm{CFU} \mathrm{mL}{ }^{-1}$. Microorganisms were cultivated in Erlenmeyer flasks on a thermostatically controlled shaker ( 160 rotation per minute) at $28^{\circ} \mathrm{C}$ for $72-168 \mathrm{~h}$.

The capacity of Pseudomonas strains to synthesize auxin, IAA, was measured by immunoenzyme assay. Before the extraction of IAA, culture media were centrifuged at $10000 \mathrm{rpm}$ for $10 \mathrm{~min}$. Aliquots of supernatant were partitioned with diethyl ether according to a modified scheme with a diminished volume of extractant used for each stage of extraction and re-extraction [40]. Abscisic acid (ABA) and cytokinin purification and assay was carried out as described [41]. An enzyme-linked immunosorbent assay was carried out as described $[18,41]$.

The ability to mobilize phosphates was evaluated by measuring the size of transparent zones on Pikovskaya medium [42]. The acetylene reduction assay was used as a measure of bacterial nitrogenase activity, with ethylene used as a marker and measured by gas chromatography [43].

Effect of Pseudomonas strains on plants was studied using seedlings of oats (Avena sativa L., cv. Konkur), barley (Hordeum vulgare L., cv. Chelyabinskiy), Sudan grass (Sorghum $\times$ drummondii, cv. Chishminskaya early), pea (Pisum sativum L., cv. Chishminskaya 229), smooth brome (Bromus inermis Leyss, cv. Chishminskaya 3), meadow fescue (Festuca pratensis Huds., cv. Ufimka) and clover (Trifolium pratense L., cv. Early 2). Preparations for seed inoculation were obtained by cultivating bacteria for 3 days in the liquid King B medium. Seed inoculation was carried out by soaking in bacterial suspension $\left(10^{5}\right.$ bacterial cells per seed) for an hour-s. Control seeds were similarly soaked 
in water. Seeds were placed in Petri dishes ( 20 seeds per dish in 10 replicates for each variant) on moistened filter paper or sowed in containers with $60 \mathrm{~g}$ of soil and incubated for 7 days at $20^{\circ} \mathrm{C}$ under illumination about $100 \mu \mathrm{mol} \mathrm{m} \mathrm{m}^{-2}$. The soil was artificially polluted with oil in concentrations of 50 and $80 \mathrm{~g} \mathrm{~kg}^{-1}$. Humidity was maintained at $80 \%$. Germination percentage, seedling mass, shoot length and total length of primary roots were measured 7 days after seed soaking.

\section{Statistics}

Data were expressed as means \pm standard error, which were calculated in all treatments using MS Excel. Significant differences between means were analyzed by a $t$-test.

Author Contributions: Conceptualization, M.B. and O.L.; methodology, E.K. and G.K.; software, S.C.; validation, L.V. and G.R.; formal analysis, G.K. and M.D.; investigation, E.K., D.C., G.R., L.V., T.A., T.K., S.C., M.B.; resources, O.L. and G.K.; data curation, T.K. and E.K.; writing-original draft preparation, G.K. and M.B.; writing-review and editing, T.K. and S.C.; visualization, E.K. and L.V.; project administration, O.L.; funding acquisition, O.L. All authors have read and agreed to the published version of the manuscript.

Funding: This research was funded by the Russian Foundation for Basic Research, grant number 18-29-05025, as part of the hormone and plant studies. The study was partly supported by funding for the themes AAAA-A19-119021390081-1 and AAAA-A18-118022190100-9 by the Ministry of Science and Higher Education of the Russian Federation.

Conflicts of Interest: The authors declare no conflicts of interest.

\section{References}

1. Afzal, M.; Khan, Q.M.; Sessitsch, A. Endophytic bacteria: Prospects and applications for the phytoremediation of organic pollutants. Chemosphere 2014, 117, 232-242. [CrossRef] [PubMed]

2. Fox, C.H.; O'Hara, P.D.; Bertazzon, S.; Morgan, K.; Underwood, F.E.; Paquet, P.C. A preliminary spatial assessment of risk: Marine birds and chronic oil pollution on Canada's pacific coast. Sci. Total Environ. 2016, 573, 799-809. [CrossRef] [PubMed]

3. Varjani, S.; Gnansounou, E.; Gurunathan, B.; Pant, D.; Zakaria, Z. Polycyclic aromatic hydrocarbons from petroleum oil industry activities: Effect on human health and their biodegradation. In Waste Bioremediation, Energy, Environment and Sustainability; Springer: Singapore, 2018; pp. 185-199.

4. Muratova, A.Y.; Dmitrieva, T.V.; Panchenko, L.V.; Turkovskaya, O.V. Phytoremediation of oil-sludge-contaminated soil. Int. J. Phytoremediat. 2008, 10, 486-502. [CrossRef] [PubMed]

5. Fatima, K.; Imran, A.; Naveed, M.; Afzal, M. Plant-bacteria synergism: An innovative approach for the remediation of crude oil contaminated soils. Soil Environ. 2017, 6, 93-113. [CrossRef]

6. Hatami, E.; Abbaspour, A.; Dorostkar, V. Phytoremediation of a petroleum-polluted soil by native plant species in Lorestan Province, Iran. Environ. Sci. Pollut. Res. Int. 2018, 22. [CrossRef] [PubMed]

7. Khan, S.; Afzal, M.; Iqbal, S.; Khan, Q.M. Plant-bacteria partnerships for the remediation of hydrocarbon contaminated soils. Chemosphere 2013, 90, 1317-1332. [CrossRef]

8. Fatima, K.; Afzal, M.; Imran, A.; Khan, Q.M. Bacterial rhizosphere and endosphere populations associated with grasses and trees to be used for phytoremediation of crude oil contaminated soil. Bull. Environ. Contam. Toxicol. 2015, 94, 314-320. [CrossRef]

9. Benson, A.; Ram, G.; John, A.; Joe, M.M. Inoculation of 1-aminocyclopropane-1-carboxylate deaminase-producing bacteria along with biosurfactant application enhances the phytoremediation efficiency of Medicago sativa in hydrocarbon-contaminated soils. Bioremediat. J. 2017, 21, 20-29. [CrossRef]

10. Korshunova, T.Y.; Chetverikov, S.P.; Bakaeva, M.D.; Kuzina, E.V.; Rafikova, G.F.; Chetverikova, D.V.; Loginov, O.N. Microorganisms in the elimination of oil pollution consequences (review). Appl. Biochem. Microbiol. 2019, 55, 344-354. [CrossRef]

11. Gkorezis, P.; Daghio, M.; Franzetti, A.; Van Hamme, J.D.; Sillen, W.; Vangronsveld, J. The Interaction between plants and bacteria in the remediation of petroleum hydrocarbons: An environmental perspective. Front Microbiol. 2016; 7, 1836. [CrossRef]

12. Glick, B.R. Modifying a plant's response to stress by decreasing ethylene production. In Phytoremediation and Rhizoremediation. Theoretical Background. Focus on Biotechnology; Mackova, M., Dowling, D., Macek, T., Eds.; Springer: Dordrecht, The Netherlands, 2006; Volume 9A, pp. 227-236. 
13. Hou, J.; Liu, W.; Wang, B.; Wang, Q.; Luo, Y.; Franks, A.E. PGPR enhanced phytoremediation of petroleum contaminated soil and rhizosphere microbial community response. Chemosphere 2015, 138, 592-598. [CrossRef]

14. Agnello, A.C.; Bagard, M.; van Hullebusch, E.D.; Espositob, G.; Huguenot, D. Comparative bioremediation of heavy metals and petroleum hydrocarbons co-contaminated soil by natural attenuation, phytoremediation, bioaugmentation and bioaugmentation-assisted phytoremediation. Sci. Total Environ. 2016, 563-564, 693-703. [CrossRef] [PubMed]

15. Gerhardt, K.E.; Huang, X.-D.; Glick, B.R.; Greenberg, B.M. Phytoremediation and rhizoremediation of organic soil contaminants: Potential and challenges. Plant Sci. 2009, 176, 20-30. [CrossRef]

16. Rubin, R.L.; van Groenigen, K.J.; Hungate, B.A. Plant growth promoting rhizobacteria are more effective under drought: A meta-analysis. Plant Soil 2017, 416, 309-323. [CrossRef]

17. Ullah, S.; Ashraf, M.; Asgar, H.N.; Iqbal, Z.; Ali, R. Plant growth promoting rhizobacteria mediated amelioration of drought in crop plants. Soil Environ. 2019, 38, 1-20. [CrossRef]

18. Kudoyarova, G.R.; Vysotskaya, L.B.; Arkhipova, T.N.; Kuzmina, L.Y.; Galimsyanova, N.F.; Sidorova, L.V.; Gabbasova, I.M.; Melentiev, A.I.; Veselov, S.Y. Effect of auxin producing and phosphate solubilizing bacteria on mobility of soil phosphorus, growth rate, and P acquisition by wheat plants. Acta Physiol. Plant. 2017, 39, 253. [CrossRef]

19. Travaglia, C.; Masciarelli, O.; Fortuna, J.; Marchetti, G.; Cardozo, P.; Lucero, M.; Zorza, E.; Luna, V.; Reinoso, H. Towards sustainable maize production: Glyphosate detoxification by Azospirillum sp. and Pseudomonas sp. Crop Prot. 2015, 77, 102-109. [CrossRef]

20. Han, Y.-Y.; Han, G.; Li, K.-R.; Zhang, X.-X. Effects of brassinolide on photosynthetic parameters of Robinia pseudoacacia seedlings in petroleum polluted soil. Nat. Environ. Pollut. Technol. 2017, 16, 199-204.

21. Spaepen, S.; Vanderleyden, J. Auxin and plant-microbe interactions. Cold Spring Harb. Perspect. Biol. 2011, 3. [CrossRef]

22. Shi, T.-Q.; Peng, H.; Zeng, S.-Y.; Ji, R.-Y.; Shi, K.; Huang, H.; Ji, X. Microbial production of plant hormones: Opportunities and challenges. Bioengineered 2017, 8, 124-128. [CrossRef]

23. Kudoyarova, G.; Arkhipova, T.; Korshunova, T.; Bakaeva, M.; Loginov, O.; Dodd, I.C. Phytohormone mediation of interactions between plants and non-symbiotic growth promoting bacteria under edaphic stresses. Front. Plant Sci. 2019, 10, 1368. [CrossRef]

24. Golubev, S.N.; Muratova, A.Y.; Wittenmayer, L.; Bondarenkova, A.D.; Hirche, F.; Matora, L.Y.; Merbach, W.; Turkovskaya, O.V. Rhizosphere indole-3-acetic acid as a mediator in the Sorghum bicolor-phenanthrene-Sinorhizobium melilotiinteractions. Plant Physiol. Biochem. 2011, 49, 600-608. [CrossRef] [PubMed]

25. Korshunova, T.Y.; Chetverikov, S.P.; Loginov, O.; Ramírez-Bahena, M.-H.; Igual, J.M.; Peix, Á. Pseudomonas turukhanskensis sp. nov., isolated from oil-contaminated soils. Int. J. Syst. Evol. Microbiol. 2016, 6, 4657-4664. [CrossRef] [PubMed]

26. Vignesh, R.; Arularasan, A.; Gandhiraj, V.; Deepika, R.C. Isolation identification and characterization of potential oil degrading bacteria from oil contaminated sites. Int. Res. J. Eng. Technol. 2016, 3, 2503-2508.

27. Koshlaf, E.; Ball, A.S. Soil bioremediation approaches for petroleum hydrocarbon polluted environments. AIMS Microbiol. 2017, 3, 25-49. [CrossRef]

28. Xu, J.G.; Johnson, R.L. Nitrogen dynamics in soils with different hydrocarbon contents planted to barley and field pea. Can. J. Soil Sci. 1997, 77, 453-458. [CrossRef]

29. Kamath, R.; Rentz, J.A.; Schnoor, J.L.; Alvarez, P.J.J. Phytoremediation of hydrocarbon-contaminated soils: Principles and applications. In Petroleum Biotechnology: Developments and Perspectives Studies in Surface Science and Catalysis; Vazquez-Duhalt, R., Quintero-Ramirez, R., Eds.; Elsevier Science: Oxford, UK, 2004; Volume 51, pp. 447-478.

30. Shtangeeva, I.; Perämäki, P.; Niemelä, M.; Kurashov, E.; Krylova, Y. Potential of wheat (Triticum aestivum L.) and pea (Pisum sativum) for remediation of soils contaminated with bromides and PAHs. Int. J. Phytoremediat. 2018, 20, 560-566. [CrossRef]

31. Dickinson, S.J.; Rutherford, P.M. Utilization of biosolids during the phytoremediation of hydrocarbon-contaminated soil. J. Environ. Qual. 2006, 35, 982-991. [CrossRef]

32. Soleimani, M.; Afyuni, M.; Hajabbasi, M.A.; Nourbakhsh, F.; Sabzalian, M.R.; Christensen, J.H. Phytoremediation of an aged petroleum contaminated soil using endophyte infected and non-infected grasses. Chemosphere 2010, 81, 1084-1090. [CrossRef] 
33. Ertekin, O.; Erol, C.; Unlu, S.; Yildizhan, Y.; Pelitli, V.; Yuksel, B.; Memon, A. Aliphatic hydrocarbon fingerprints in Trifolium spp. Fresenius Environ. Bull. 2011, 20, 367-371.

34. Chetverikov, S.P.; Sharipov, D.A.; Korshunova, T.Y.; Loginov, O.N. Degradation of perfluorooctanyl sulfonate by strain Pseudomonas plecoglossicida 2.4-D. Appl. Biochem. Microbiol. 2017, 53, 533-538. [CrossRef]

35. Nie, M.; Wang, Y.; Yu, J.; Xiao, M.; Jiang, L.; Yang, J.; Fang, C.; Chen, J.; Li, B. Understanding plant-microbe interactions for phytoremediation of petroleumpolluted soil. PLOS ONE 2011, 6, e17961. [CrossRef] [PubMed]

36. Glick, B.R. Bacteria with ACC deaminase can promote plant growth and help to feed the world. Microbiol. Res. 2014, 169, 30-39. [CrossRef] [PubMed]

37. Lane, D.J. 16S/23S rRNA sequencing. In Nucleic Acid Techniques in Bacterial Systematic; Stackebrandt, E., Goodfellow, M., Eds.; John Wiley and Sons: Chichester, UK, 1991; pp. 115-177.

38. Raymond, R.L. Microbial oxidation of n-paraffinic hydrocarbons. Develop. Ind. Microbiol. 1961, 2, $23-32$.

39. King, E.O.; Ward, M.K.; Raney, D.E. Two simple media for the demonstration of pyocyanin and fluorescein. J. Lab. Clin. Med. 1954, 44, 301-307. [PubMed]

40. Veselov, S.Y.; Kudoyarova, G.R.; Egutkin, N.L.; Guili-Zade, V.Z.; Mustafina, A.R.; Kof, E.M. Modified solvent partitioning scheme providing increased specificity and rapidity of immunoassay for indole 3- acetic acid. Physiol. Plant. 1992, 86, 93-96. [CrossRef]

41. Kudoyarova, G.R.; Melentiev, A.I.; Martynenko, E.V.; Timergalina, L.N.; Arkhipova, T.N.; Shendel, G.V.; Kuz'mina, L.Y.; Dodd, I.C.; Veselov, S.Y. Cytokinin producing bacteria stimulate amino acid deposition by wheat roots. Plant Physiol. Biochem. 2014, 83, 285-291. [CrossRef]

42. Pikovskaya, R.I. Mobilization of phosphorus in soil in connection with vital activity of some microbial species. Mikrobiologiya 1948, 17, 362-370.

43. Hardy, R.W.F.; Burns, R.C.; Holsten, R.D. Application of the acetylene-ethylene assay for measurement of nitrogen fixation. Soil Biol. Biochem. 1973, 5, 47-81. [CrossRef]

(C) 2020 by the authors. Licensee MDPI, Basel, Switzerland. This article is an open access article distributed under the terms and conditions of the Creative Commons Attribution (CC BY) license (http://creativecommons.org/licenses/by/4.0/). 